DUNAMIS (Jurnal Teologi dan Pendidikan Kristiani)

Volume 1, Nomor 2, April 2017

ISSN 2541-3937 (print), 2541-3945 (online)

http://www.sttintheos.ac.id/e-journal/index.php/dunamis

Submit: 05 April 2017

Accept: 30 April 2017

Publishe: 30 April 2017

\title{
Analisis Kata Murtad dalam Kitab Ibrani 6:4-6
}

\author{
Elkana Chrisna Wijaya \\ Sekolah Tinggi Teologi Harvest Semarang \\ chrisna.wijaya@yahoo.co.id
}

\begin{abstract}
The term of "fall way" in Hebrews 6:4-6 has been debated by theologians in distinguished perspectives. This study aims to describe and analyze the word of apostasy in Hebrews 6:6, so it would give a biblical undestanding, according to both authors' purpose of writing this book and its first readers. The result of this analysis would give a contribution to pragmatic and theological thought at present time. The conclucion of this study is, that the word of "fall away" in Hebrews 6:4-6 is not related to salvation at all. That word is closely related to reward, because it mostly refers to a Christian commitment. Thus, in certain point, believer could be in position of fall away, where that believer keep himself away from living relationship with Jesus the lorf. That situation doesn't affect believers' salvation, but the lost of his reward which shall be received before judgement seat of Christ.
\end{abstract}

Keywords: analysis; book of Hebrew; debate; fall away; reward; salvation

\begin{abstract}
Abstrak
Makna kata "murtad" dalam Kitab Ibrani 6:4-6 telah lama diperdebatkan oleh para sarjana Alkitab dalam spektrum teologis yang beragam. Penelitian ini bermaksud untuk menganalisis dan mendeskripsikan kata "murtad" dalam Ibrani 6:6, sehingga menghasilkan pemahaman makna kata yang alkitabiah, yang sesuai dengan maksud penulis kitab Ibrani, serta yang dipahami oleh pembaca pertamanya. Hasil analisis akan memberikan kontribusi pemikiran teologis dan pragmatis pada masa kini. Kesimpulan dari penelitian ini menjelaskan bahwa kata "murtad" dalam Ibrani 6:4-6 sama sekali tidak berhubungan dengan keselamatan. Kata tersebut berhubungan erat dengan upah, karena lebih mengacu kepada komitmen orang Kristen. Dengan demikian, pada situasi atau titik tertentu, orang percaya dapat berada pada posisi "murtad", bahwa orang tersebut melakukan tindakan menjauhkan diri dari persekutuan yang hidup dengan Tuhan Yesus. Keberadaan tersebut tidak mempengaruhi keselamatan orang percaya, namun berkaitan dengan risiko hilangnya pahala atau upah yang akan diterima orang-orang percaya di hadapan takhta pengadilan Kristus.
\end{abstract}

Kata Kunci: analisis; keselamatan; kitab Ibrani; murtad; pahala/upah; perdebatan 
PENDAHULUAN

Perdebatan tentang makna kata "murtad" dalam Kitab Ibrani 6:4-6 telah lama diperdebatkan oleh para sarjana Alkitab dalam spektrum teologis yang beragam. Perdebatan itu menjadi semakin tajam dan menarik karena tampaknya masing-masing pihak telah dipengaruhi oleh pandangan tertentu yang bersifat denominasional atau pribadi. Setiap denominasi memiliki kerangka berpikir yang bersifat dogmatis dan dijadikan kerangka acuan dalam memahami setiap bagian dalam Alkitab. Setiap denominasi memiliki cara dan kerangka teologi dalam penafsiran, yang sejatinya tidak dapat mengklaim bahwa kelompok atau golongannyalah yang paling benar dalam menafsirkan. Menurut Bob Utley, seorang Guru Besar Hermeneutik, bahwa penafsiran alkitabiah adalah suatu proses spiritual dan rasional, di mana penafsir mencoba memahami tulisan (teks) dari para penulis Alkitab yang diilhami Tuhan pada jaman dulu. sedemikian hingga berita dari Tuhan itu dapat dimengerti dan diterapkan pada jaman kita sekarang ini. ${ }^{1}$

Dalam proses penafsiran harus ada yang disebut dengan proses spiritual. Proses spiritual adalah suatu proses yang sangat

\footnotetext{
${ }^{1}$ Bob Utley, "Anda Dapat Memahami Alkitab," dalam Keunggulan Perjanjian Baru: Ibrani, Vol. 10 (Marshall: Bible Lesson International, 1999), 1.
}

menentukan namun sukar untuk didefinisikan. Proses ini melibatkan sifat keterbukaan dan kepasrahan kepada Tuhan. Harus ada kelaparan akan firman Tuhan untuk mengenal Tuhan sehingga dapat melayani-Nya. Proses ini memerlukan doa, pengakuan dan kesediaan untuk merubah gaya hidup. Peranan Roh sangatlah menentukan dalam proses penafsiran ini, namun mengapa banyak Kristen yang sunguh-sungguh dan hidup kudus memahami Alkitab secara berbeda adalah suatu misteri.

Selain itu ada juga proses rasional. Proses rasional lebih mudah untuk dijelaskan. Kita harus bersikap konsisten adil terhadap suatu naskah dan tidak boleh dipengaruhi oleh pandangan-pandangan yang bersifat denominasional ataupun kepribadian. Kita semua secara historis telah dipengaruhi oleh suatu pandangan tertentu. Tak satupun dari kita yang bisa menjadi penafsir yang benar-benar netral dan obyektif, karena pengaruh berbagai pandangan yang sudah menghiasi dalam pikiran kita.

Adanya pengaruh pandangan tertentu tersebut mengakibatkan perdebatan mengenai kata "murtad" dalam Ibrani 6:4-6 belum mencapai sebuah pemahaman yang "memuaskan" masing-masing pihak, bahkan semakin melahirkan isu-isu teologis yang berkaitan dengan kata "murtad" 
tersebut. Di antaranya adalah mengenai isu keselamatan, upah, dan iman. Dari beberapa isu yang muncul tersebut, salah satu yang dianggap menarik dan perlu untuk ditinjau dan dikaji secara mendalam adalah mengenai persoalan-persoalan khas yang berhubungan dengan kehidupan iman dalam kehidupan kekristenan abad pertama, terutama dalam hal ini adalah kata “murtad" yang terdapat dalam Ibrani 6:4-6.

Hal tersebut dikarenakan munculnya banyak pertanyaan klasik dan kontroversial yang berhubungan dengan kata "murtad" itu sendiri, seperti: Apakah orang yang berpindah keyakinan itu disebut sebagai orang murtad? Atau apakah orang pindah dari agama Kristen ke agama lain itu adalah orang murtad? Dalam kekristenan, apakah ada jalan pertobatan bagi orang murtad? Apakah sekali selamat tetap selamat selamanya, sekalipun murtad? Dikatakan klasik, karena pertanyaan-pertanyaan tersebut seringkali dimunculkan dan menjadi polemik hingga hari ini, baik dalam kelas di sekolah teologi, kelas pendalaman Alkitab, seminar, khususnya manakala kata murtad tersebut dimunculkan. Kontroversial, dikarenakan jawaban-jawaban yang diberikan seringkali mendapatkan sanggahan dan ketidakpuasan dari pihak-pihak tertentu. Dengan kata lain, belum mendapatkan kata sepakat mengenai isu tersebut, baik di kalangan akademisi maupun praktisi.

\section{METODE}

Metode yang digunakan dalam arikel penelitian ini adalah metode eksesgesis dengan pendekatan analisis kata sesuai dengan teks aslinya. Peneliti mencari makna dari kata murtad yang ada pada teks Ibrani 6:4-6 dengan memahami konteks penulis dan pembaca pertamanya. Pemahaman teks pada konteks zaman pembaca pertama akan membawa pada penerapan pada konteks masa kini.

Kata yang dianalisi adalah kata "murtad" yang dalam pemahaman umum secara sekilas merupakan perubahan yang terjadi pada seseorang karena perubahan keyakinannya. Namun pada penelitian ini pemahaman itu diambil dari pemahaman biblikal yang diterapkan secara kontekstual.

\section{Latar Belakang Penerima Surat Ibrani}

Penyelidikan terhadap pemahaman kata "murtad" dalam Ibrani 6:4-6, menghadapi problem tersendiri, dikarenakan penerima surat Ibrani adalah masalah yang belum terpecahkan. ${ }^{2}$ Hal itu dikarenakan dalam surat itu sendiri tidak ada petunjuk yang jelas kepada siapa surat ini semula

\footnotetext{
${ }^{2}$ George Eldon Ladd, A Theology of the New Testament (Grand Rapids, Michigan: William B. Eerdmans Publishing Company, 1975), 571.
} 
ditujukan. ${ }^{3}$ Munculnya beberapa pandangan yang spekulatif, mulai dari pandangan tradisional yang menyatakan bahwa surat Ibrani ditujukan kepada komunitas Yahudi Kristen, kemungkinan di Roma (Ibrani 13:24) yang sedang dihadapkan pada penganiayaan. Komunitas Yahudi tersebut terancam untuk murtad (apostasy) dari imannya kepada Kristus dan kembali kepada Yudaisme," 4 sampai pada keyakinan bahwa surat ini ditulis dan ditujukan untuk orang Kristen non-Yahudi. ${ }^{5}$

Sehubungan dengan hal tersebut, tentunya harus diambil sebuah keputusan yang dapat dipertanggungjawabkan mengenai kejelasan dari penerima kitab Ibrani, mengingat bahwa penerima surat menentukan makna yang sebenarnya dari kata "murtad." Dave Hagelberg memberikan keyakinan bahwa orang-orang Yahudi Kristenlah yang menerima surat ini. ${ }^{6}$ Surat Ibrani dikirim kepada orangorang Kristen yang terdiri dari orang-orang Yahudi yang sudah percaya kepada Mesias mereka, yaitu Tuhan Yesus. Surat ini bisa dianggap ditulis untuk orang-orang Kristen Yahudi karena tema yang dibicarakan

\footnotetext{
${ }^{3}$ A.M. Stibbs, "Ibrani," dalam Tafsiran Alkitab Masa Kini, pen. Harun Hadiwijono, Jil. 3 (Jakarta: Yayasan Komunikasi Bina Kasih, 1992), 719.

${ }^{4}$ Ladd, Op.Cit., 571

${ }^{5}$ Stibbs, "Ibrani," dalam Tafsiran Alkitab Masa Kini, 3:719.
}

${ }^{6}$ Dave Hagelberg, Tafsiran Ibrani dalam

Bahasa Yunani (Bandung: Kalam Hidup, 1993), 36. dalam surat ini merupakan hal yang sudah lazim bagi orang-orang yang terbiasa dengan tema-tema dari Perjanjian Lama. Ada kejelasan surat ini ditulis untuk orangorang percaya oleh karena penulis surat Ibrani selalu menyebut pembacanya orangorang percaya, saudara-saudara seiman. Hal tersebut dapat ditunjukkan dari ayat-ayat berikut, bahwa surat Ibrani ditujukan kepada orang orang percaya, yakni: Ibrani $2: 1-3 ; \quad 3: 1 ; \quad 5: 11-14 ; 6: 4-5 ; 6: 10 ; 6: 19$; $10: 19 ; 10: 32 ; 10: 35 ; 10: 36 ; 12: 1 ; 13: 1$; 13:15-16; 13:17. Ayat-ayat tersebut membuktikan bahwa surat ini ditujukan kepada orang-orang percaya untuk menguatkan mereka, dan bukan untuk menginjili orang-orang yang belum percaya, karena ayat-ayat ini tidak sesuai kalau ditujukan kepada orang yang belum menerima Tuhan Yesus sebagai Juruselamatnya.

Penjelasan yang serupa diberikan oleh R.C. Glaze yang dikutip oleh Bob Utley mengenai orang-orang Kristen Yahudi sebagai penerima surat Ibrani $^{7}$, bahwa mereka sepertinya adalah orang Yahudi yang percaya karena banyaknya kutipan nas Perjanjian Lama dan masalah pokok bahasannya (lihat Ibr. 3:1; 4:14-16; 6:9; $10: 34 ; 13: 1-25)$. Mereka telah mengalami beberapa penganiayaan (Ibr. 10:32; 12:4).

\footnotetext{
${ }^{7}$ R.C. Glaze, Jr. Tak Ada Keselamatan yang Mudah, yang dikutip oleh Bob Utley dalam Keunggulan Perjanjian Baru: Ibrani, 3.
} 
Yudaisme diakui sebagai suatu agama resmi oleh penguasa Romawi sementara di kemudian hari di abad pertama kekristenan dianggap tidak sah ketika terpisah dari ibadah di sinagoge. Mereka telah cukup lama menjadi orang percaya, namun belum dewasa (Ibr. 5:11-14). Mereka takut untuk memisahkan diri sepenuhnya dari Yudaisme (Ibr. 6:1-2).

Ross, juga menegaskan dalam tulisannya mengenai penerima surat Ibrani adalah orang-orang Kristen Yahudi, dalam empat pandangan ${ }^{8}$, bahwa surat ini ditujukan kepada orang-orang Kristen Yahudi yang tinggal di Yerusalem dan sekitarnya. Berikutnya dikatakan bahwa surat ini ditujukan kepada orang-orang Kristen Yahudi yang tinggal di Aleksandria. Pandangan ini cenderung dianut oleh mereka yang mendukung anggapan adanya warna Aleksandria yang kuat di dalam surat ini. Ada pandangan juga bahwa surat ini ditujukan bagi sebuah jemaat Kristen Yahudi yang beribadah di Roma dan berada dalam pencobaan dan penganiayaan yang berat.

Pandangan tentang "jemaat di Roma" juga cenderung menganut teori "satu jemaat," yakni bahwa para penerima pertama surat ini adalah sebuah jemaat kecil, atau suatu persekutuan rumah tangga

${ }^{8}$ Ross, "Ibrani," dalam Tafsiran Alkitab Wycliffe, 3:919. di Roma. Sebuah modifikasi dari jemaat yang dituju oleh surat Ibrani merupakan jemaat yang kecil, tetapi mereka bisa berada di mana saja di wilayah kerajaan Romawi, dan tidak harus di Roma.

Meskipun ada empat pandangan yang dikemukakan di atas, namun perbedaan pandangan tersebut hanya sebatas mengemukakan perbedaan lokasi si penerima surat. Pada kenyataannya keempat pandangan ini menunjuk bahwa orang-orang Kristen Yahudi yang menerima surat tersebut. Secara khusus dalam Ibrani 6:4-5, tertulis “. . . mereka yang pernah di terangi hatinya...yang pernah mengecap karunia sorgawi, dan yang pernah mendapat bagian dalam Roh Kudus, dan yang mengecap firman yang baik dari Allah dan karunia-karunia dunia yang akan datang," yang dengan jelas menegaskan bahwa penulis surat Ibrani ini sedang menjelaskan kondisi orang-orang yang percaya kepada Yesus atau yang “pernah" percaya kepada Yesus. Kondisi tersebut juga dipakai oleh penulis dalam Ibrani 10:32, sebagai berikut: "Ingatlah akan masa yang lalu. Sesudah kamu menerima terang, kamu banyak menderita oleh karena kamu bertaham dalam perjuangan yang berat..." Frasa "sesudah kamu menerima terang" sejajar dengan frasa "yang pernah diterangi hatinya," yang 
mana keduanya berhubungan dengan orang-orang yang percaya.

Jadi surat Ibrani yang ditulis kurang lebih pada tahun $64-68^{9}$, ditujukan kepada orang-orang percaya Yahudi. Yaitu orangorang Kristen Yahudi yang berada dalam penganiayaan atau tekanan dan bertujuan untuk menguatkan atau meneguhkan orangorang percaya tersebut.

\section{PEMBAHASAN DAN HASIL}

Beberapa perbedaan pendangan tentang tafsiran kata murtad menurut Ibrani 6:6 didaftarkan Dave Hagelberg dalam buku "Tafsiran Ibrani dalam Bahasa Yunani", dalam beberapa pandangan ${ }^{10}$ :

Pertama, bahwa keselamatan mereka akan hilang sehingga mereka sedang menuju neraka, meskipun mereka pernah percaya dan lahir baru. Kedua, ada sesuatu yang tidak beres dalam iman mereka, sehingga mereka tidak pernah diselamatkan, mereka hanya "mengecap keselamatan, tetapi tidak "memakannya." Yang ketiga, pandangan yang mengtakan bahwa ayat ini hanya menceritakan suatu pengandaian saja, yaitu seandainya keselamatan mereka hilang, orang itu tidak tertolong lagi. Yang keempat, mereka adalah orang yang sudah selamat, tetapi yang menjauhkan diri dari persekutuan

\footnotetext{
${ }^{9}$ Gleason L. Archer Jr. The Epistle to the Hebrews: A Study Manual (Grand Rapids: Baker Book House, 1957)

${ }^{10}$ Hagelberg, Op.Cit., 36
}

yang hidup dengan Tuhan Yesus sehingga pahala mereka terancam.

Berdasarkan pertimbangan atau alasanalasan di atas, maka ada beberapa tujuan yang hendak dicapai oleh penulis dalam penulisan ini, yaitu meliputi: Pertama, penulis bermaksud untuk menganalisis dan mendeskripsikan kata "murtad" dalam Ibrani 6:6, sehingga menghasilkan pemahaman makna kata yang alkitabiah, yang sesuai dengan maksud si penulis kitab Ibrani, dan yang dipahami oleh pembaca asli pada masa itu. Kedua, penulis bertujuan untuk memberikan kontribusi pemikiran teologis dan pragmatis, terutama berkaitan dengan pertanyaan-pertanyaan yang bersifat klasik dan kontroversial yang telah diungkapkan di atas. Dalam hal ini penulis berupaya untuk mengesampingkan pengaruh dari pandangan "denominasional" ataupun pandangan "pribadi," dengan menempatkan dan menyakini bahwa Alkitab adalah Firman Allah yang benar tanpa salah, menjadi sumber jawaban dan memiliki otoritas yang tertinggi dari segala persoalan atau masalah, baik itu teologis, etis dan praktis.

\section{Makna Kata "Murtad" dalam Ibrani 6:6}

Upaya memahami makna sebuah kata dalam teks Alkitab, tentunya tidak dapat terlepas aspek-aspek yang berhubungan dengan kata tersebut. Pemahamanpemahaman mengenai pribadi penerima 
surat Ibrani, definisi dari kata "murtad" itu sendiri, dan analisis dari kata itu sendiri. Dengan demikian, perlu untuk terlebih dahulu memaparkan beberapa bagian yang mendukung proses penemuan pemahaman makna kata "murtad" dalam Ibrani 6:4-6. Pemaparan tersebut meliputi: latar belakang penerima surat Ibrani, definisi istilah dan makna eksegetikal kata "murtad" dalam Ibrani 6:4-6, serta kesimpulan.

\section{Definisi Istilah}

Kata "murtad" dalam Kamus Besar Bahasa Indonesia memiliki arti: "berputar ke belakang, berbalik arah, membuang iman." 11 Dalam pemahaman bahasa Indonesia, kata "murtad" seringkali digunakan untuk menyebut orang-orang yang meninggalkan agama yang lama dan masuk ke agama yang baru atau seseorang yang meninggalkan atau melepaskan iman yang lama dan menerima iman yang baru.

Ensiklopedi Alkitab Masa Kini menjelaskan bahwa kata "murtad" dalam istilah kata Yunani apostasia, merupakan teknis untuk revolusi politik atau penyeberangan seseorang kepada musuh. Dalam LXX kata itu dihubungkan dengan pemberontakan terhadap Allah (Yos. 22:22;

\footnotetext{
${ }^{11}$ Tim Prima Pena, Kamus Besar Bahasa Indonesia, (Jakarta: Gitamedia Press, tt), 544.
}

2 Taw. 29:19). ${ }^{12}$ Secara umum kata "murtad" berhubungan dengan kata Yunani

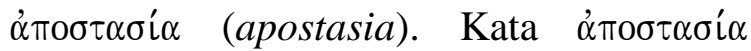
(apostasia) dalam Vine's Expository Dictionary, memiliki makna "sebuah pembelotan, pemberontakan, kemurtadan (apostasy), yang digunakan dalam Perjanjian Baru dari kemurtadan agama." 13

Berdasarkan pengertian-pengertian di atas, maka secara teknis, kata "murtad" (apostasia) memiliki pengertian: "Tindakan pengkhianatan atau pemberontakan yang ditujukan kepada Allah agama.

\section{Makna Eksegetikal}

Teks Ibrani 6:4-6, dalam Lembaga Alkitab Indonesia secara lengkap dan lieral adalah sebagai berikut:

${ }^{4}$ Sebab mereka yang pernah diterangi hatinya, yang pernah mengecap karunia sorgawi, dan yang pernah mendapat bagian dalam Roh Kudus, ${ }^{5}$ dan yang mengecap firman yang baik dari Allah dan karunia-karunia dunia yang akan datang, ${ }^{6}$ namun yang murtad lagi, tidak mungkin dibaharui sekali lagi sedemikian, hingga mereka bertobat, sebab mereka menyalibkan lagi Anak Allah bagi diri mereka dan menghinaNya di muka umum.

Hagelberg menterjemahkan kata "murtad" dalam Ibrani 6:6, dengan pengertian "jatuh dari (Allah)." ${ }^{14}$ Alkitab

\footnotetext{
${ }^{12}$ A.S. Wood, "Murtad," dalam Ensiklopedi Alkitab Masa Kini 2 Jilid (Jakarta; Yayasan Komunikasi Bina Kasih, 1997), 2:101.

${ }^{13}$ W.E. Vine, "avpostasi,a (apostasia)," dalam Vine's Expository Dictionary (Nashville: Thomas Nelson Publishers, 1997), 403.

${ }^{14}$ Hagelberg, Tafsiran Ibrani, 37.
} 
King James Version, Ibrani 6:6, mengenai keberadaan orang-orang Yahudi menggunakan frasa "to fall away" dalam menuliskan kata murtad, yang artinya "meninggalkan kepercayaan." Dari ayatayat di atas, Hagelberg memberikan penjelasan bahwa berdasarkan tata bahasa, terdapat lima kata kerja aorist partisiple, yang terdiri dari kata: diterangi, mengecap, menjadi (mendapat bagian) sekali lagi mengecap, dan akhirnya murtad. ${ }^{15}$

Kata "murtad" dalam Ibrani 6:6, menggunakan kata Yunani $\pi \alpha \rho \alpha \pi \epsilon \sigma o ́ \nu \tau \alpha \varsigma$ (parapesontas), berasal dari kata dasar $\pi \alpha \rho \alpha \pi \iota \pi \tau \omega$ (parapipto), dari dua akar kata Yunani $\pi \alpha \rho \alpha$ (para) yang artinya "di samping, jauh" dan $\pi \iota \pi \tau \omega$ (pipto) yang artinya "jatuh." Kata $\pi \alpha \rho \alpha \pi \iota \pi \tau \omega$ (parapipto), secara harafiah berarti "meninggalkan dengan cara, menyatakan meninggalkan (dari kepatuhan/kepercayaan terhadap realitas dan fakta-fakta dari iman)."16

Kata kerja aorist aktif partisiple $\pi \alpha \rho \alpha \pi \epsilon \sigma o ́ \nu \tau \alpha \varsigma \quad$ (parapesontas), secara harafiah memiliki pengertian "tindakan meninggalkan kepercayaan/iman/Allah pada satu titik waktu tertentu/tidak terusmenerus." Mengacu pada pengertian tersebut, maka Ibrani 6:4-6 menjelaskan

\footnotetext{
${ }^{15}$ Ibid.
}

${ }^{16}$ W.E. Vine, " $\pi \alpha \rho \alpha \pi \iota \pi \tau \omega$ (parapipto)," dalam Vine's Expository Dictionary (Nashville: Thomas Nelson Publishers, 1997), 404. 
selamat tetap selamat, sehingga cenderung mengabaikan tanggung jawab manusia. ${ }^{17}$

Rasul Paulus sendiri dalam surat yang ditujukan kepada jemaat di Efesus, menegaskan bahwa: "Sebab karena kasih karunia kamu diselamatkan oleh iman; itu bukan hasil usahamu, tetapi pemberian Allah, itu bukan hasil pekerjaanmu: jangan ada orang yang memegahkan diri.",18

Menanggapi kedua pandangan dan penjelasan Rasul Paulus mengenai keselamatan, Hagelberg yang menyakini bahwa Ibrani 6:4-6 mengacu kepada “orang yang sudah selamat, tetapi yang menjauhkan diri dari persekutuan yang hidup dengan Tuhan Yesus sehingga pahala mereka terancam." ${ }^{19}$ Penjelasan tersebut menegaskan bahwa kemurtadan yang dimaksud, sama sekali tidak berkaitan dengan keselamatan, melainkan berkaitan dengan risiko kehilangan "pahala/upah." Hagerlberg memberikan komentar mengenai frasa "tidak mungkin dibaharui sekali lagi sedemikian, hingga mereka bertobat" sebagai sebuah pekerjaan yang tidak mungkin dapat dilakukan oleh manusia namun mungkin oleh Tuhan. ${ }^{20}$

Penulis surat Ibrani tidak bermaksud menyatakan bahwa hal ini tidak mungkin bagi Allah. Ia mungkin bermaksud

\footnotetext{
${ }^{17}$ Chris Marantika, Diktat Kuliah: Soteriologi (Yogyakarta: STTII, 1995).

${ }^{18}$ Efesus 2:8-9.

${ }^{19}$ Hagelberg, Tafsiran Ibrani, 36.

${ }^{20}$ Ibid., 37.
}

menyatakan bahwa hal ini tidak mungkin bagi manusia. Istilah yang dipakai di sini untuk terjemahan "tidak mungkin" adalah kata $\alpha \delta v \nu \alpha \tau o \varsigma / a d u n a t o s$. Istilah ini juga dipakai dalam Matius 19:26, di mana Tuhan Yesus berkata, "Bagi manusia hal ini tidak mungkin, tetapi bagi Allah segala sesuatu mungkin."

Hodges juga memberikan penjelasan bahwa: "Pada dasarnya kata "murtad" tidak mengacu pada hilangnya kehidupan kekal yang, seperti Injil Yohanes jelaskan, bahwa hal itu adalah milik mutlak dari mereka yang percaya kepada Kristus." ${ }^{21}$ Pandangan tersebut didasarkan pada penjelasan Hodges mengenai kata "murtad" dalam Ibrani 6:4-6 yang telah ditafsirkan ke dalam empat cara $^{22}$, sebagai berikut:

Pertama, bahwa bahaya orang Kristen kehilangan keselamatannya dijelaskan, sebuah pandangan yang telah ditolak karena jaminan Alkitab bahwa keselamatan merupakan karya Allah yang tidak dapat dilindungi. Kedua, bahwa peringatan ini melawan hanya profesi mengenai iman kerdil keselamatan, atau mencicipi tapi tidak benar-benar mengambil bagian dari keselamatan (The New Scotfield Reference Bible, p. 1315). Ketiga, adanya dugaan jika orang Kristen bisa kehilangan

\footnotetext{
${ }^{21}$ Hodges, "Hebrews," in The Bilble Knowledge Commentary, 795.

${ }^{22}$ Hodges, "Hebrews," in The Bilble Knowledge Commentary, 794.
} 
keselamatannya, tidak ada ketentuan untuk pertobatan (The Ryrie Study Bible, p. 1843);

Keempat, bahwa sebuah peringatan telah diberikan mengenai bahaya dari orang Kristen yang pindah dari posisi iman yang sejati dan hidup sampai batas menjadi didiskualifikasi untuk layanan lebih lanjut (1Kor. 9:27) dan untuk menerima warisan kemuliaan kerajaan milenium.

Untuk menafsirkan kalimat "sebab mereka menyalibkan lagi Anak Allah bagi diri mereka dan menghina-Nya di muka umum," Hodges menjelaskan bahwa frasa "kehilangan mereka" mungkin lebih baik diterjemahkan "sehubungan dengan kehormatan mereka sendiri." Orang-orang yang meninggalkan iman Kristen mereka, sehubungan dengan kehormatan perilaku dan sikap mereka sendiri, mengambil langkah seperti kebanyakan masyarakat menolak Kristus. Ketika mereka pertama kali percaya kepada-Nya, mereka dengan demikian mengakui bahwa penyaliban-Nya tidak adil dan hasil dari manusia yang penuh dosa yang menolak penyelamat. Tetapi dengan menyangkal pendapat ini, mereka menegaskan kembali pandangan musuh Yesus bahwa Ia pantas mati di kayu salib. Dalam hal ini, "mereka (adalah" menyalibkan Anak Allah lagi. Karena penyaliban asli adalah karya utama bangsa Yahudi, jika para pembaca yang Yahudi menjadi terpikat kembali ke dalam beberapa bentuk agama leluhur mereka, frasa penulis ini menghasilkan poin tertentu. $^{23}$

Jadi Hodges menjelaskan mengenai kata "murtad" seperti melangkah kembali melewati garis lagi, dan sekali lagi mengungkapkan solidaritas dengan rekanrekan mereka yang ingin Yesus disalibkan. ${ }^{24}$ Ini adalah yang paling serius dan menjadi poin penulis. Orang-orang tersebut tidak bisa dimenangkan kembali ke keadaan pertobatan yang ditandai perubahan asli mereka kepada kekristenan. Dalam menegaskan hal ini, perkataan penulis menunjukkan bahwa kekerasan hati mereka telah menentang semua upaya untuk memenangkan mereka kembali untuk memiliki komitmen Kristiani, dan tidak sekedar berganti identitas Kristen saja.

Penulis sendiri menyetujui kedua pakar di atas, bahwa kata "murtad" dalam Ibrani 6:4-6, sama sekali tidak berhubungan dengan "kehidupan kekal," (keselamatan). Dan karena berhubungan dengan komitmen Kristen, maka kata tersebut lebih tepat jika dihubungkan dengan pahala/upah yang akan diterima atau tidak diterima oleh orang-orang percaya, sebagaimana yang dituliskan Paulus, sebagai berikut: "Sebab kita semua harus menghadap takhta pengadilan Kristus, supaya setiap orang

\footnotetext{
${ }^{23}$ Ibid., 795.

${ }^{24}$ Ibid.
} 
memperoleh apa yang patut diterimanya, sesuai dengan yang dilakukannya dalam hidupnya ini, baik ataupun jahat.",25

\section{KESIMPULAN}

Setelah melakukan studi eksegetikal dan menganalisis kata "murtad" dalam kitab Ibrani 6:4-6, maka kesimpulannya adalah sebagai berikut:

Pertama, penerima kitab Ibrani adalah menunjuk kepada orang-orang Kristen Yahudi. Yaitu orang-orang Kristen Yahudi yang berada dalam penganiayaan atau tekanan dan bertujuan untuk menguatkan atau meneguhkan orang-orang percaya tersebut. Orang-orang percaya tersebut karena tekanan/penganiayaan yang dialaminya pada satu titik tertentu dapat meninggalkan keyakinannya pada Tuhan Yesus, dan kembali kepada ajaran agama leluhur (Yudaisme) mereka.

Kedua, kata "murtad" dalam Ibrani 6:46, sama sekali tidak berhubungan dengan "kehidupan kekal," (keselamatan). kata tersebut berhubungan erat dengan pahala/upah, karena lebih mengacu kepada komitmen Kristiani/pertumbuhan rohani orang percaya.

Ketiga, dalam menanggapi isu keselamatan dalam kehidupan orang percaya, penulis memberikan pendapat bahwa orang percaya bisa saja berada pada posisi "murtad" dengan pengertian bahwa orang tersebut melakukan tindakan menjauhkan diri dari persekutuan yang hidup dengan Tuhan Yesus. Tetapi keberadaan tersebut tidak mempengaruhi keselamatan orang percaya, karena keberadaan tersebut berkaitan dengan resiko hilangnya pahala/upah yang akan

diterima orang-orang percaya di hadapan takhta pengadilan Kristus. Dengan demikian keselamatan orang Kristen adalah keselamatan yang tidak mengabaikan tanggung jawab manusia. Jika tanggung jawab manusia diabaikan, maka orangorang percaya tersebut akan kehilangan pahala. Yohanes menuliskan demikian: "Waspadalah, supaya jangan kehilangan apa yang telah kami kerjakan itu, tetapi supaya kamu mendapat upahmu sepenuhnya." 26 "Aku datang segera, peganglah apa yang ada padamu, supaya tidak seorangpun mengambil mahkotamu.",27

\section{DAFTAR PUSTAKA}

Alkitab. Jakarta: Lembaga Alkitab Indonesia, 2002.

Alkitab dalam Bahasa Indonesia-Yunani. Jakarta: Lembaga Alkitab Indonesia, 1998.

Archer, Gleason L. Jr. The Epistle to the Hebrews: A Study Manual. Grand Rapids: Baker Book House, 1957.

\footnotetext{
${ }^{25} 2$ Korintus 5:10.
} 
Glaze, R.C. Jr. "Tak Ada Keselamatan yang Mudah", dalam Utley, Bob. Keunggulan Perjanjian Baru: Ibrani Hagelberg, Dave. Tafsiran Ibrani dalam Bahasa Yunani, Bandung: Kalam Hidup, 1993.

Hodges, Zane C. "Hebrews," in The Bilble Knowledge Commentary. Pen., John F. Walvoord and Roy B. Zuck. USA: Victor Books, 1995. [terjemahan langsung]

Ladd, George Eldon. A Theology of the

New Testament. Grand Rapids,

Michigan: William B. Eerdmans

Publishing Company, 1975.

Marantika, Chris. Diktat Kuliah:

Soteriologi. Yogyakarta: STTII, 1995.

Ross, Robert W. "Ibrani," dalam Tafsiran

Alkitab Wycliffe. Peny., Charles F.

Pfeiffer dan Everett F. Harrison, vol. 3.

Malang: Gandum Mas, 2001.

Stibbs, A. M. "Ibrani," dalam Tafsiran

Alkitab Masa Kini. Pen., Harun
Hadiwijono. Jil., 3. Jakarta: Yayasan Komunikasi Bina Kasih, 1992.

Utley, Bob. "Anda Dapat Memahami Alkitab," dalam Keunggulan Perjanjian Baru: Ibrani. Vol., 10 Marshall, Texas: Bible Lesson International, 1999.

Tim Prima Pena. Kamus Besar Bahasa Indonesia, Jakarta: Gitamedia Press, tt.

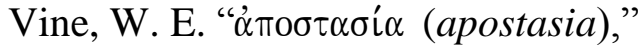
dalam Vine's Expository Dictionary, Nashville: Thomas Nelson Publishers, 1997.

Vine's Expository Dictionary.

Nashville: Thomas Nelson Publishers, 1997.

Wood, A. S. "Murtad," dalam Ensiklopedi Alkitab Masa Kini, 2 Jilid, Jakarta; Yayasan Komunikasi Bina Kasih, 1997 